\title{
Path Analysis of Sociodemography Determinants, Sexual Behavior, and HIV Status in Sragen, Central Java
}

\author{
Fiqih Agustyna Murti'), Argyo Dermatoto'), Bhisma Murti') \\ ${ }^{1)}$ Masters Program in Public Health, Universitas Sebelas Maret \\ 2)Department of Sociology, Faculty of Social and Political Sciences, Universitas Sebelas Maret
}

\section{ABSTRACT}

Background: HIV/ AIDS is a global problem, including Indonesia. HIV/ AIDS sufferers in Sragen Regency have increased every year. Sociodemographic factors and the many places as hosts for sexual behavior are the causes of HIV cases that cannot be suppressed. The purpose of this study was to determine the determinants of sociodemography, sexual behavior and HIV status.

Subjects and Method: This was a cross sectional study conducted in Sragen Regency, Central Java, from August to December 2018. The sample consisted of 200 residents who did VCT. The sampling technique chosen was fixed disease sampling. The dependent was HIV status. The independent variables were occupation, knowledge of sexual partner HIV status, social support, sexual behavior and locus of control. Data were collected using a questionnaire and analyzed using path analysis.

Results: HIV risk increased directly with risky work $(b=7.5 ; 95 \% \mathrm{CI}=0.79-1.42 ; \mathrm{p}=0.029)$, risky sexual behavior $(\mathrm{b}=0.48 ; 95 \% \mathrm{CI}=-0.63-$ 1.73; $\mathrm{p}=0.405$ ), and sexual partners who did not know the HIV status of their sexual partners $(b=0.48 ; 95 \% \mathrm{CI}=-0.63$ to $1.73 ; \mathrm{p}=$ $0.405)$. HIV risk is indirectly influenced by locus of control, social support, occupation, and sexual partners who do not know the HIV status of their sexual partners through sexual behavior.

Conclusion: HIV status is directly influenced by occupation, sexual behavior and knowledge of sexual partners' HIV status, as well as indirectly by locus of control, social support, occupation and knowledge of sexual partners HIV status through sexual behavior.

Keywords: HIV, sociodemographic, sexual behavior

\section{Correspondence:}

Fiqih Agustyna Murti. Masters Program in Public Health, Universitas Sebelas Maret. Jl. Ir. Sutami 36A, Surakarta 57126, Central Java. Email: murti.fiqih@gmail.com. Mobile: +6285729752541.

\section{Cite this as:}

Murti FA, Dermatoto A, Murti B (2020). Path Analysis of Sociodemography Determinants, Sexual Behavior, and HIV Status in Sragen, Central Java. J Health Promote Behav. 05(04): 240-247. https://doi.org/10.26911/thejhpb.2020.05.04.02.

(i) (2) Journal of Health Promotion and Behavioris licensed under a Creative Commons

\section{Attribution-NonCommercial-ShareAlike 4.o International License.}

\section{BACKGROUND}

Human Immunodeficiency Virus (HIV) is a virus that attacks white blood cells. HIV attacks and destroys the immune system so that it will make the immune system decrease and susceptible to other diseases. HIV will survive in human body fluids, especially in leukocytes (white blood cells) (Demartoto et al., 2017). HIV is the virus that causes AIDS or Acquired Immune
Deficiency Syndrome. AIDS is the last stage in people who are infected with HIV (Stolly et al., 2009). HIV infection type 1 has clinical symptoms similar to type 2 . But type 1 is more contagious and has a shorter period of infection. This is why HIV-1 attacks more than HIV-2 (Demartoto et al., 2017).

The clinical manifestations that arise in people with AIDS are caused by progressive damage to the immune system, 
making it very vulnerable and susceptible to various kinds of infections. AIDS is a set of media conditions or what is called a follow-up infection (Demartoto et al., 2017). HIV progresses to AIDS in a person taking eight to 10 years after being infected with HIV. People infected with HIV will be given ARV (Antiretroviral) treatment to prevent AIDS (Stolly et al., 2009). Various inherent factors make HIV/ AIDS cases not easy to accept. Keluru sexual behavior causes the transmission of HIV/ AIDS infection. HIV infection is transmitted through semen and vaginal fluids during sexual intercourse (Stolly et al., 2009; Ramaiah et al., 2008).

The wrong behavior about health will have an impact on the health of oneself or even others (Bandura, 2001). Ama et al. (2015) stated that sociodemographic factors are related to people's attitudes and behavior. HIV incidence results from social and economic imbalances. The existence of localization also affects HIV status in adults. This study aimed to examine the determinants of sexual behavior and HIV status in Sragen, Central Java.

\section{SUBJECTS AND METHOD}

\section{Study Design}

This was an analytic epidemiological study with a cross sectional design. The study was carried out in Sragen Regency, Central Java, Indonesia, from August to December 2018.

\section{Population and Sample}

The population of this study were residents in Sragen Regency, either HIV positive or negative. The sample in this study were residents diagnosed as HIV positive (cases) as well as residents diagnosed as HIV negative (controls) with a total of 60 people who were HIV positive, 140 students with negative HIV status, so the total sample in this study was 200 respondents. The sampling technique in this study was fixed disease sampling.

Subjects met the inclusion and exclusion criteria as follows:

a. Inclusion Criteria

1) Reproductive age $\geq 15$ years

2) Willing to be a respondent

b. Exclusion Criteria

1) Change of domicile/moving

2) Died

\section{Variables}

The dependent variable was HIV status. The independent variables were occupation, knowledge of HIV status from sexual partners, social support, sexual behavior and locus of control.

\section{Operational Definition of Variables} HIV status is the result of a positive or negative HIV test based on a VCT test using a dichotomy scale of positive and negative HIV results.

Occupation is an activity or task that is designed to be carried out for those who are at risk of contracting HIV directly or indirectly or not. Risky occupation (housewives, sales business in shops and markets, prostitutes, health personnel, private employees, freelancers, salon or nursing workers, masseuses). Work without risk (civil servants, teachers, farmers, traders, scavengers, self-employed).

Knowledge of the HIV status of a sexual partner is a condition that is recognized and recognized by the sexual partner of the respondent regarding their HIV status. Assessment is measured by not knowing and knowing.

Social support is the act of family, friends or sexual partners in the form of emotions, information, instruments and judgments in dealing with problems. Low social support with a value $<$ Median and high with a value $\geq$ Median.

Sexual behavior is sexual activity related to HIV transmission. This behavior is based 
on risk behavior ( $<$ Median) and non-risk behavior ( $\geq$ Median).

Locus of control is the respondent's belief as a control center for the success of the action on his own will or from outside influence. External locus of control with a value of $<$ Median and internal locus of control with a value of $\geq$ Median.

\section{Data Instrument}

HIV status, occupation, knowledge about sexual partner HIV status, social support, sexual behavior and locus of control were obtained using a questionnaire.

\section{Data Analysis}

Univariate analysis was carried out to see the frequency distribution and percentage characteristics of the research subjects. Bivariate analysis was performed to study the relationship between HIV status and the independent variables using the chisquare test and calculation of odds ratios (OR) with a confidence level (CI) of 95\%.

Table 1. Sample Characterstics

\begin{tabular}{lcc}
\hline \multicolumn{1}{c}{ Variable } & n & Persentage (\%) \\
\hline HIVStatus & & \\
$\quad$ Positive & 60 & 30.0 \\
$\quad$ Negative & 140 & 70.0 \\
Occupation & & \\
$\quad$ Risky & 98 & 49.0 \\
$\quad$ Not risky & 102 & 51.0 \\
Knowledge about HIVStatus & & \\
$\quad$ Not knowing & 85 & 42.5 \\
$\quad$ Knowing & 115 & 57.5 \\
Locus of Control & & 36.0 \\
$\quad$ External & 72 & 64.0 \\
$\quad$ Internal & 128 & 33.0 \\
Social Support & & 67.0 \\
$\quad$ Low & 66 & 43.5 \\
$\quad$ High & 134 & 56.5 \\
Sexual Behavior & & \\
$\quad$ Risky & 87 & \\
Not risky & 113 & \\
\hline
\end{tabular}

Table 2 shows the relationship between the independent variables (sex behavior, knowledge of HIV status, locus of control, social support and job status) with
Furthermore, multivariate analysis was carried out using path analysis.

\section{Ethical Clearance}

Research ethics in this study include informed consent, anonymity, confidentiality and ethical clearance. Ethical clearance in this study was obtained from Universitas Sebelas Maret, Surakarta, in 2018.

\section{Univariate Analysis}

Table 1 shows that 60 (30\%) of the people who are HIV positive. Residents with risky jobs are as many as 98 (49\%). There were $85(42.5 \%)$ residents who had known the HIV status of their sexual partners. Residents with low locus of control were as many as 72 (36\%). People who received low social support were as many as 66 (33\%). People with risky sexual behavior were as many as 87 (43.5\%). the dependent variable (HIV status). The results of the complete bivariate analysis can be seen in Table 2 . 
Murti et al./ Sociodemography Determinants, Sexual Behavior, and HIV Status

Tabel 2. Analysis of the relationship between sex behavior, knowledge of HIV status, locus of control, social support, and job status on HIV status

\begin{tabular}{|c|c|c|c|c|c|c|c|c|c|}
\hline \multirow[t]{2}{*}{$\begin{array}{c}\text { Independent } \\
\text { Variable }\end{array}$} & \multicolumn{2}{|c|}{$\begin{array}{c}\text { Positive } \\
\text { HIV }\end{array}$} & \multicolumn{2}{|c|}{$\begin{array}{l}\text { Negative } \\
\text { HIV }\end{array}$} & \multicolumn{2}{|c|}{ Total } & \multirow{2}{*}{ OR } & \multirow[t]{2}{*}{$95 \%$ CI } & \multirow{2}{*}{$\mathbf{p}$} \\
\hline & $\mathbf{N}$ & $\%$ & $\mathbf{N}$ & $\%$ & $\mathbf{n}=\mathbf{2 0 0}$ & $\%$ & & & \\
\hline \multicolumn{10}{|l|}{ Job Status } \\
\hline Risky & 39 & 19.5 & 59 & 29.5 & 98 & 49.0 & 2.5 & 1.37 to 4.78 & 0.003 \\
\hline Not Risky & 21 & 10.5 & 81 & 40.5 & 102 & 51.0 & & & \\
\hline \multicolumn{10}{|l|}{$\begin{array}{l}\text { Knowledge of } \\
\text { HIV Status }\end{array}$} \\
\hline Not knowing & 30 & 19.0 & 55 & 27.5 & 85 & 42.5 & 1.54 & 0.84 to 2.84 & 0.160 \\
\hline Knowing & 30 & 15.0 & 85 & 42.0 & 115 & $57 \cdot 5$ & & & \\
\hline \multicolumn{10}{|l|}{ Locus of } \\
\hline Control & 31 & $15 \cdot 5$ & 41 & 20.5 & 72 & 36.0 & 2.59 & 1.39 to 4.81 & 0.003 \\
\hline External & 29 & 14.5 & 99 & 49.5 & 128 & 64.0 & & & \\
\hline \multirow{2}{*}{\multicolumn{10}{|c|}{$\begin{array}{l}\text { Internal } \\
\text { Social Support }\end{array}$}} \\
\hline & & & & & & & & & \\
\hline Low & 29 & 14.5 & 37 & 18.5 & 66 & 33.0 & 2.60 & 1.39 to 4.90 & 0.003 \\
\hline High & 31 & 15.5 & 103 & 51.5 & 134 & 67.0 & & & \\
\hline \multicolumn{10}{|l|}{ Sex Behavior } \\
\hline Risky & 34 & 17.0 & 53 & 26.5 & 87 & 43.5 & 2.14 & 1.17 to 3.97 & 0.014 \\
\hline Not risky & 26 & 13.0 & 87 & 43.5 & 113 & 56.5 & & & \\
\hline
\end{tabular}

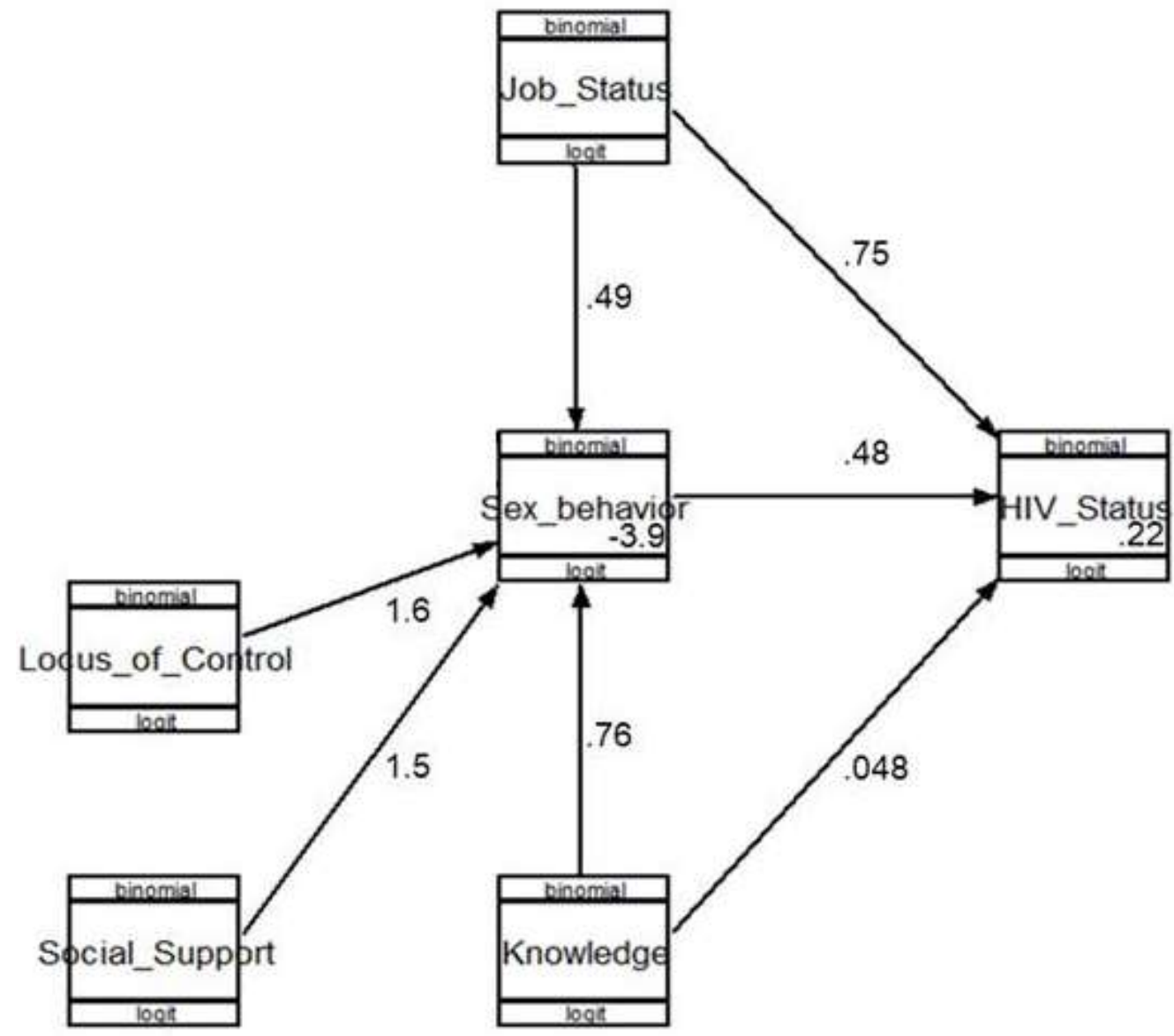

Figure 1. Path Analysis Diagram 
Murti et al./ Sociodemography Determinants, Sexual Behavior, and HIV Status

\section{Multivariate analysis using path analysis}

Multivariate analysis describes the effect of more than one independent variable on one dependent variable. The method used is path analysis using the STATA 14 program.

Figure 1 shows a path diagram of analysis on sociodemographic determinants (occupation, knowledge of sexual partner HIV status, social support and locus of control), sexual behavior and HIV status. Table 3 shows the results of the path ana- lysis for the dependent and independent variables with the Log likelihood value191.87 .

Table 3 shows that employment has a direct effect on the increase in HIV cases $(b=0.75 ; 95 \% \mathrm{CI}=0.79$ to; $1.42 \mathrm{p}=0.029$ ). HIV status is indirectly influenced by locus of control, social support, knowledge about HIV status of sexual partners and HIV status through sexual behavior. Sexual behavior itself has no effect on HIV status.

Table 3: Path Analysis Results of the factors affecting HIV Status

\begin{tabular}{|c|c|c|c|c|c|}
\hline \multirow{2}{*}{$\begin{array}{c}\text { Independent } \\
\text { Variables }\end{array}$} & & \multirow{2}{*}{$\begin{array}{c}\text { Path } \\
\text { Coefficient } \\
\text { (b) }\end{array}$} & \multicolumn{2}{|c|}{ 95\% CI } & \multirow[b]{2}{*}{$\mathbf{p}$} \\
\hline & & & $\begin{array}{l}\text { Lower } \\
\text { Limit }\end{array}$ & $\begin{array}{l}\text { Upper } \\
\text { Limit }\end{array}$ & \\
\hline \multicolumn{6}{|l|}{ Direct Effect } \\
\hline \multirow[t]{3}{*}{ HIV Status } & $\leftarrow$ Job Status (risky) & 0.75 & 0.79 & 1.42 & 0.029 \\
\hline & $\leftarrow$ Sex Behavior (risky) & 0.48 & -0.22 & 1.42 & 0.180 \\
\hline & $\leftarrow \begin{array}{l}\text { Knowledge (Not } \\
\text { knowing) }\end{array}$ & 0.48 & -0.63 & 0.73 & 0.405 \\
\hline \multicolumn{6}{|l|}{ Indirect Effect } \\
\hline \multirow[t]{4}{*}{ Sexual behavior } & $\leftarrow$ Job Status (Risky) & 0.49 & -0.33 & 1.31 & 0.247 \\
\hline & $\leftarrow \begin{array}{l}\text { Knowledge } \\
\text { (Not knowing) }\end{array}$ & 0.77 & -0.08 & 1.60 & 0.077 \\
\hline & $\leftarrow \begin{array}{l}\text { Social Support } \\
\text { (low) }\end{array}$ & 1.50 & 0.54 & 2.43 & 0.002 \\
\hline & $\leftarrow \begin{array}{l}\text { Locus of Control } \\
\text { (External) }\end{array}$ & 1.57 & 0.69 & 2.45 & $<0.001$ \\
\hline \multicolumn{6}{|c|}{ Number of Observed $=200$} \\
\hline
\end{tabular}

\section{DISCUSSION}

1. The Effect of Occupation on HIV Status

The results of the analysis show that there is a direct effect of work on a person's HIV status and it is statistically significant Occupations at risk increased HIV risk ( $b=0.75$; 95\% $\mathrm{CI}=0.79$ to; $1.42 \mathrm{p}=0.029$ ).

The occupations that directly improve HIV status are IRTs and health workers. These jobs are jobs that can be associated with people who are HIV positive but accidentally catch them.
The community thinks that if someone has a high work status, then they may have many children because they are able to meet the needs of daily life (Hastono, 2009). Certain occupations have a risk of being infected with HIV (Meiliyana, 2014). This is because gender discrimination, inequality, education, inadequate health services, poverty, and violence are factors that increase the risk of HIV (UNAIDS, 2016a).

Employment also indirectly through sexual behavior improves HIV status. The occupations in question are commercial sex 
workers, business sales in shops and markets, private employees, freelancers, salon or parlor workers, masseuses. The results of this study are in line with Ashley (2010) which explains that women are one of the objects infected with HIV. This vulnerability that occurs in women is caused by changing sexual patterns for commercial survival.

\section{The Effect of Sexual Behavior on HIV Status}

The analysis showed that sexual behavior had a direct effect on a person's HIV status although it was not statistically significant $(b=0.48 ; 95 \% \mathrm{CI}=-0.63-1.73 ; \mathrm{p}=0.405)$. Risk sexual behavior has a log odds of HIV status that is 0.48 greater than that of nonrisk sexual behavior. Sexual behavior has the potential to increase a person's HIV risk. This is in line with Jiang et al. (2018) who showed that new infections occurred in people with homosexual behavior or causal sex partners. Haley et al. (2017) showed that there was sexual intercourse without a condom $(\mathrm{OR}=0.49)$ on HIV status.

A study conducted by Mabaso et al. (2018) showed that there was a relationship between one sexual partner $(\mathrm{OR}=0.43)$ and HIV status. Late use of condoms also increases a person's HIV status $(\mathrm{OR}=0.53)$.

Risk sexual behavior turns out to be diverse and not only for commercial sex workers but also for housewives (IRT), sales businesses in shops and markets, health workers, private employees, freelancers, salon or nursing workers, or masseuses.

\section{The Effect of Knowledge of Sexual Partner's HIV Status on HIV Status}

The results of the analysis indicated that there was a direct influence between knowledge of the HIV status of sexual partners on the HIV status of the partners, although it was not statistically significant. Sexual partners who did not know their partner's
HIV status had a log odds of HIV risk 0.48 greater than sexual partners who knew their partner's HIV status.

Knowledge of a sexual partner's HIV status has the potential to increase a person's HIV risk $(b=0.48 ; 95 \% \mathrm{CI}=-0.63$ - 1. 73; $\mathrm{p}=0.405$ ).

The results of this study are in line with Erku et al. (2012) who explained that there was a significant relationship between knowing a partner's HIV sexual status $(\mathrm{aOR}=8.1)$ and disclosing HIV status to sexual partners. This is supported by Obermeyer (2011) who explains that the disclosure of the status of a non-permanent sexual partner is lower than that of a sexual partner who is permanent.

Couples who do not know their partner's HIV status also indirectly increase their risk of HIV through unsafe sexual behavior.

\section{The Effect of Locus Of Control on HIV Status}

The analysis showed that locus of control had an indirect effect on HIV status through sexual behavior. The external locus of control had a log-odd score of HIV status 1.57 greater than the internal locus of control. Locus of control has the potential to increase a person's HIV risk through sexual behavior $(b=1.57 ; 95 \% \mathrm{CI}=0.69$ to 2.45; $\mathrm{p}<0.001$ ).

Locus of control will affect a person's behavior, especially in health care, which is related to sexual behavior. This behavior is influenced either from the individual himself or from outside the individual. The locus of external control has a greater effect on individual behavior than the internal one.

The results of this study are in line with Burke's (2013) statement which states that the perception of benefits will improve the quality of life both physically and emotionally. According to Glanz et al. (2008) perceived severity also affects a person's 
mindset. The amount of resistance as a perception of severity results in bad behavior.

\section{The Effect of Social Support on HIV Status}

The analysis showed that social support had an indirect effect on HIV status through sexual behavior and was statistically significant. Low social support has a log odds score of HIV status that is 1.50 greater than people who have high social support. Social support has the potential to increase a person's HIV risk through sexual behavior $(b=1.50 ; 95 \% \mathrm{CI}=0.54-2.43 ; \mathrm{p}=0.002)$.

Low social support will have an impact on individual sexual behavior. High social support will increase awareness of their own health so that individuals will pay attention to their sexual behavior.

The results of this study are in line with Chen's (2017) study which shows that greater social support $(\mathrm{aOR}=1.04)$ is more likely to test for HIV. Taylor et al. (2009) explained that social support actually strengthens immune function, reduces physiological responses to stress, and strengthens the response function to chronic disease.

The conclusion of this study is that there is a direct influence between occupation and knowledge of sexual partners' HIV status on HIV status. There is an indirect influence between sexual behavior on HIV status and work, locus of control, social support, knowledge of HIV status sexual partners have an indirect effect on HIV status through sexual behavior.

\section{AUTHOR CONTRIBUTION}

Fiqih Agustyna Murti is the main author. He conducts research, collects data, and analyzes data and concludes research data. Bhisma Murti is the one who formulates theories, research frameworks and analyzes research data. Dr Argyo Dermantoto is the one who formulates theories, research frameworks and analyzes research data.

CONFLICT OF INTEREST

There is no conflict of interest in this study.

FUNDING AND SPONSORSHIP

This study is self-funded.

\section{ACKNOWLEDGEMENT}

We would like to thank the Sragen Regency Health Office for the research permit given. We also thank the peer support group of Sragen Regency for their collaboration in research. Thanks to the respondents for their participation as subject.

\section{REFERENCE}

Ama NO, Vijai KD, Sheila S, Denise B (2015). Socio-economic and demographic determinants of HIV status among HIV infected older adults (5064 years) in Botswana: Evidence from 2013 Botswana AIDS impact survey (BAIS IV). J AIDS Clin Res. 6(4): 1000448. doi:10.4172/2155-6113.1000448.

Bandura A (1977). Self-efficacy: Toward a uniflying theory of behavioral change. Phychological Review. 84(2): 191-215. https://doi.org/10.1016/0146-6402(78)90002-4.

Chen W, Zhou F, Hall BJ, Tucker JD, Latkin C, Renzaho AMN, Ling L (2017). Is there a relationship between geographic distance and uptake of HIV testing services? A representative population-based study of Chinese adults in Guangzhou, China. Public Library of Science. 12(7): Eo180801. https://doi.org/10.1371/journal.pone.0180801.

Demartoto A, Zunariyah S, Soemanto RB (2017). Pendidikan Sebaya Terstruktur Responsif AIDS (AIDS Responsive 
Murti et al./ Sociodemography Determinants, Sexual Behavior, and HIV Status

Structured Peer Education). Surakarta: CV Kekata Group.

Erku TA, Megabiaw B, Wubshet M (2012). Predictors of HIV status disclosure to sexual partners among people living with HIV/AIDS in Ethiopia. Pan African Med J. 13(87): 1-2. http://www.ncbi.nlm.nih.gov/pmc/articles/ pmc3567411/.

Glanz K, Rimer BK, Viswanath K (2008). Health behavior and health education: Theory, research, and practice. San Francisco, CA: Jossey - Bass.

Haley DF, Hardorfer R, Kramer MR, Adimora AA, Wingood GM, Goswami ND, Rubtsova A, et al. (2017). Associations between neighborhood characteristics and sexual risk behaviors among HIV - infected and HIV Uninfected women in the Southern United States. Annals Epidemiol. 27(4): 252-259. https://doi.org/10.1016/j.annepidem.2017.03.004.

Hastono SP (2009). Analisa Lanjut SDKI 2007. Peran faktor komposisional dan faktor kontekstual terhadap jumlah anak yang diinginkan di Indonesia: Permodelan dengan analisis multilevel (The role of compositional factors and contextual factors on the number of desired children in Indonesia: Modeling with multilevel analysis). Jakarta: Puslitbang KB dan KesehatanReproduksi BKKBN.

Jiang J, Zha LQ, Ruan JJ, Yang JZ, Zhu BX, Chen L, He L, et al. (2018). Sources and characteristics of newly reported HIV/AIDS cases in Yiwu, Zhejiang
Province, 2015-2016. Pubmed. 39(1): 21-26. https://doi.org/10.3760/cma.j.issn.0254-6450.2018.01.004

Mabaso M, Sokhela Z, Mohlabane N, Chibi B, Zuma K, Simbayi L (2018). Determinants of HIV infection among adolescent girls and young women aged 15 - 24 years in South Africa: A 2012 population - based national household survey. Bio Med Central Public Health. 18(183): 1-7.

Meiliyana (2014). Faktor-faktor yang berhubungan dengan kejadian HIV (+) Pada Kalangan Lelaki Suka Lelaki (LSL) di Indonesia Tahun 2011 (Analisis Data STBP Tahun 2011. Skripsi. (Factors associated with the incidence of HIV (+) among men like men (MSM) in Indonesia in 2011 (Analysis of 2011 IBBS Data. Thesis. Depok: FKM UI.

Obermeyer CM, Baijal P, Pegurri E (2011). Facilitating HIV disclosure across diverse settings: A review. Am J Public Health. 101(6): 1011-23. https://doi.org/10.2105/ajph.2010.300102.

Ramaiah, Savitri (2008). Health Solutions HIV/ AIDS. New Delhi: Sterling Paperbacks.

Stolly, Kathy S, Glass, John E (2009). HIV/ AIDS. United States of America: Greenwood Publishing Group.

UNAIDS (2016a). Global AIDS Monitoring 2017. Indicators for monitoring the 2016 United. Nations Political Declaration on HIV and AIDS. Accessed October 2017. 